\title{
Geomorphology and stream habitat relationships with smallmouth bass (Micropterus dolomieu) abundance at multiple spatial scales in eastern Oklahoma
}

\author{
Daniel C. Dauwalter, Dale K. Splinter, William L. Fisher, and Richard A. Marston
}

\begin{abstract}
Fluvial geomorphic processes structure habitats important to stream fishes. We determined relationships between densities of smallmouth bass (Micropterus dolomieu) and ecoregions, watershed and reach morphology, and stream habitat in eastern Oklahoma, USA. Watershed and reach morphology were measured at 128 stream sites, and stream habitat and smallmouth bass abundance were measured in 1800 channel units. Variation in stream size, channel morphology, and substrate size constituted major physical differences among sites. Channel morphology differed among ecoregions in the largest streams. Densities of age- 0 and age- 1 and older smallmouth bass were approximately an order of magnitude greater in the Boston Mountains and Ozark Highlands streams than in Ouachita Mountains streams. Regression tree analysis explained less variation in age-0 $(10$-fold cross-validated relative error $=0.843)$ than in age- 1 and older (relative error $=0.650$ ) smallmouth bass densities and showed that stream size and channel-unit size were primary determinants of density. Channel morphology explained variation in densities in deep channel units of large streams, which was somewhat independent of ecoregion.
\end{abstract}

Résumé : Les mécanismes de géomorphologie fluviale structurent les habitats qui sont importants pour les poissons d'eau courante. Nous avons déterminé les relations entre les densités d'achigans à petite bouche (Micropterus dolomieu) et les écorégions, la morphologie du bassin versant et des sections, ainsi que les habitats des cours d'eau dans l'est de l'Oklahoma, É.-U. Nous avons mesuré la morphologie du bassin versant et de la section à 128 sites et déterminé l'habitat fluvial et la densité des achigans à petite bouche dans 1800 unités de chenal. Les variations de taille du cours d'eau, de la morphologie du chenal et de la granulométrie du substrat constituent les différences physiques majeures entre les sites. La morphologie du chenal varie dans les plus grands cours d'eau d'une écorégion à une autre. Les densités des achigans d'âge 0, d'âge 1 et d'âges supérieurs sont environ 10 fois plus importantes dans les cours d'eau des monts Boston et des terres hautes de l'Ozark que dans ceux des monts Ouachita. Une analyse par arbre de régression explique moins de variation (erreur relative par validation croisée en 10 parties $=0,843$ ) de la densité des achigans à petite bouche d'âge 0 que de la densité des poissons d'âge 1 ou plus (erreur relative $=0,650$ ); elle montre aussi que la taille du cours d'eau et celle de l'unité de chenal sont les principaux facteurs déterminants de la densité. La morphologie du chenal explique les variations de densité dans les unités de chenal profondes des grands cours d'eau, en partie indépendamment de l'écorégion.

[Traduit par la Rédaction]

\section{Introduction}

The processes of water, sediment, and wood transport control stream channel morphology and hydraulics and ultimately form the physical habitat in streams required by fishes (Yang 1971; Beschta and Platts 1986; Newson and
Newson 2000). Downstream transport of water, sediment, wood, and nutrients creates the longitudinal profile of streams that have unique characteristics, processes, and biota (Vannote et al. 1980). However, spatial variability in those routing processes within and among watersheds and regions exists as a result of landforms, geomorphic controls, and dis-

Received 9 May 2006. Accepted 24 March 2007. Published on the NRC Research Press Web site at cjfas.nrc.ca on 9 August 2007. J19312

D.C. Dauwalter. ${ }^{\mathbf{1} 2}$ Oklahoma Cooperative Fish and Wildlife Research Unit and Department of Zoology, Oklahoma State University, Stillwater, OK 74078, USA.

D.K. Splinter. Department of Geography and Geology, University of Wisconsin-Whitewater, WI 53190, USA.

W.L. Fisher. United States Geological Survey, Oklahoma Cooperative Fish and Wildlife Research Unit and Department of Zoology, Oklahoma State University, Stillwater, OK 74078, USA.

R.A. Marston. Department of Geography, Kansas State University, Manhattan, KS 66506, USA.

${ }^{1}$ Corresponding author (e-mail: ddauwalt@uwyo.edu).

${ }^{2}$ Present address: Department of Zoology and Physiology, Department 3166, University of Wyoming, 1000 East University Avenue, Laramie, WY 82071, USA. 
turbances that can affect local channel morphology and stream habitat within the longitudinal continuum (Montgomery 1999; Benda et al. 2004).

Channel morphology and landforms affect stream biota at different organismal and organizational levels. In an Appalachian stream, channel morphology and geomorphic controls (bedrock outcrops) influenced macroinvertebrate community structure and function (Huryn and Wallace 1987). Bull trout (Salvelinus confluentus) selected reaches for spawning that were in alluvial valleys with geomorphic controls (knickpoints) and large areas of groundwater upwelling. Within those reaches, however, bull trout built redds at the transitions of bedforms that had areas with localized downwelling (Baxter and Hauer 2000). Watershed and reach morphology have been shown to structure stream fish assemblages (Rhoads et al. 2003; Walters et al. 2003), with the importance of spatial scale being dependent on the spatial extent of the study (Gido et al. 2006). Fluvial processes acting on different spatial scales have been implicated in affecting stream habitat and biota; however, connecting these processes to stream morphology, physical habitat, and biota in streams often requires incorporation of analyses at multiple spatial scales (Frissell et al. 1986; Newson and Newson 2000; Frothingham et al. 2002).

Many stream habitat enhancement and restoration principles are based on the characteristics of watersheds, valleys, and stream channels. Rosgen (1994, 1996) developed a stream classification system to determine, in part, the potential for enhancement of fish habitat and river restoration. $\mathrm{He}$ suggested that installation of instream structures intended as fish habitat may result in detrimental channel adjustments and create disequilibrium conditions and that only streams exhibiting certain morphologic and sediment characteristics should be candidates for habitat-improvement structures. Rosgen also suggested that restoration principles should incorporate the natural stable tendencies of a river that result from the interaction of morphological variables. Champoux et al. (2003) found that long-term success of instream structures was related to different glacial deposits (moraine versus outwash plain) and argued that the glacial history and reach characteristics need to be considered during restoration planning to ensure long-term effectiveness of habitatimprovement structures and management actions.

Because stream restoration and enhancement activities incorporate the geomorphic context of streams at several spatial scales, understanding how fishes are related to the geomorphic features of streams aids the conservation and management of local stream habitats and populations of aquatic organisms. Our goal was to determine how watershed characteristics, channel morphology, and stream habitat influenced smallmouth bass (Micropterus dolomieu) abundance in streams of the Boston Mountains, Ouachita Mountains, and Ozark Highlands ecoregions in eastern Oklahoma. These ecoregions in Oklahoma encompass the southwestern extent of the native distribution of smallmouth bass.

\section{Materials and methods}

\section{Study area}

Relations between smallmouth bass abundance and watershed characteristics, channel morphology, and stream habitat were determined for small streams to midsized rivers in the
Boston Mountains, Ouachita Mountains, and Ozark Highlands level-III ecoregions in eastern Oklahoma (Omernik 1987). The Boston Mountains ecoregion is a dissected mountainous plateau composed of flat-lying shale and sandstone lithology and oak-hickory forest. Annual rainfall is $112-130 \mathrm{~cm}$ and land is used mostly for logging and recreation (Woods et al. 2005). The Ouachita Mountains consist of folded, Paleozoic sandstone, shale, and chert. Oak - hickory - shortleaf pine forests in this region receive from 109 to $145 \mathrm{~cm}$ of annual rainfall. Common land uses are logging, pastureland, hayfields, farming, and recreation (Rutherford et al. 1992; Woods et al. 2005). The Ozark Highlands are dominated by flat-lying cherty limestone, but shale, limestone, and dolomite are present in valley bottoms. Annual precipitation is $104-124 \mathrm{~cm}$, and land use is primarily logging, recreation, and cattle and poultry farming, including pastureland and hayfields (Rabeni and Jacobson 1993; Woods et al. 2005).

\section{Stream survey}

A geographic information system (GIS) was used as an aid in the random selection of 175 stream sites for an inventory of watershed and reach morphology, stream habitat, and smallmouth bass populations in the study area. To select stream sites, a stream network was generated in a GIS using a $30 \mathrm{~m}$ digital elevation model (DEM) from the National Elevation Dataset (US Geological Survey 1999). The network was created by identifying all cells in the DEM with a watershed size $\geq 1.35 \mathrm{~km}^{2}$ and defining them as a stream. Stream orders (Strahler 1957) were assigned to each stream segment in the network. One-hundred and seventy-five sample sites (sample units) were randomly selected on regional streams. Sites were allocated to the three ecoregions approximately in proportion to ecoregion area and equally distributed among stream orders 1-4 in each ecoregion to ensure that larger streams were represented. Forty sites were selected in both the Boston Mountains and Ozark Highlands ecoregions, and 95 were selected in the Ouachita Mountains ecoregion within Oklahoma. The GIS layer of sample sites was uploaded into a global positioning system (GPS) receiver that was used to navigate to each site. Streams were sampled once from mid-May to mid-August from 2003 to 2005 during low streamflow conditions.

\section{Watershed and channel morphology}

The characteristics of watersheds and stream channels associated with each stream site were measured. Watershed scale geomorphic variables for each site were derived using a GIS. The aforementioned DEM was used to delineate watersheds, and GIS was then used to measure watershed areas and lengths. Elongation ratio was measured as the diameter of a circle with the same area as the watershed divided by watershed length (Morisawa 1968).

We measured channel morphology at the reach scale. The stream reach at each site was defined as 20 times the mean channel width (i.e., bankfull width) upstream of each sample point; bankfull stage was identified by using visual and physical indicators (Rosgen 1996). Channel units in each reach were classified by relative water velocities and surface turbulence, using the scheme of Hawkins et al. (1993). Transects perpendicular to the channel were surveyed across 
two riffles and two pools when available, with a maximum of two transects in a single channel unit; two to four transects were surveyed per reach. Entrenchment ratio, width-depth ratio, and median particle size (i.e., $D_{50}$ ) were calculated for each transect. Entrenchment ratio was calculated as the ratio of flood-prone width to bankfull channel width. Flood-prone elevation was equal to twice the maximum channel depth, and flood-prone width was estimated as the valley floor width at the flood-prone elevation. Maximum flood-prone width was measured if it was less than 2.2 times the channel width at each transect, otherwise it was recorded as 2.2. Width-depth ratio was calculated as the ratio of bankfull channel width to mean bankfull channel depth. Channel depths were measured at 20 equally spaced locations along transects. Median particle size of surficial substrates was calculated by collecting 100 particles along each transect and measuring the intermediate axis of each; bedrock was excluded from analysis. Water surface slope of each reach was measured in the field with a transit level and stadia rod. Sinuosity was measured as the ratio of stream length to straight-line distance as measured on maps of the stream reach created with a GPS (see below). Width-depth ratio and median particle size for the reach were calculated from transect data as weighted averages based on the proportion of each reach length that comprised riffles and pools (Zar 1999). Reach entrenchment ratios were calculated as the median of transect values.

\section{Channel-unit habitat}

Habitat was measured in each channel unit within each reach using methods conducive to a large-scale stream survey. Channel units were mapped with a GPS, and lengths and areas of channel units were measured in a GIS (Dauwalter et al. 2006). Thalweg depths were measured multiple times per channel unit at equally spaced intervals; more measurements were made in longer and more heterogeneous channel units. A modified Wentworth scale was used to visually estimate substrate distributions within each channel unit (Bain 1999). We estimated, and enumerated when logistically feasible, boulders, rootwads, and large woody debris $(10+\mathrm{cm}$ diameter, $4+\mathrm{m}$ in length) in each channel unit. Percent undercut bank and percent vegetative coverage were also estimated. Water velocity was coded by channel-unit type (falls, 4; riffle, 3; run, 2; all other types, 1). Habitat variables for each channel unit were combined for reach habitat estimates.

\section{Smallmouth bass abundance}

Smallmouth bass abundance was estimated by snorkeling or electrofishing individual channel units within reaches. When snorkeling, 1- to 3-person snorkel teams moved upstream in a zigzag pattern and counted and estimated sizes of smallmouth bass individuals (Dolloff et al. 1996). One electrofishing pass was made throughout each channel unit using a backpack, barge, or boat electrofisher when water clarity was less than $1 \mathrm{~m}$ and prohibited effective snorkeling. Water clarity was measured as the maximum distance at which a snorkeler could see a $100 \mathrm{~mm}$ model of a smallmouth bass. Electrofishing power density was standardized at approximately $1000 \mu \mathrm{S} \cdot \mathrm{cm}^{-3}$ (Miranda and Dolan 2003); however, settings on the backpack electrofisher prohibited obtaining $1000 \mu \mathrm{S} \cdot \mathrm{cm}^{-3}$ exactly. Counted individuals were placed into $<100$ and $\geq 100 \mathrm{~mm}$ size categories. Individuals $<$ $100 \mathrm{~mm}$ represent age- 0 individuals and those $\geq 100 \mathrm{~mm}$ are age-1 and older (Balkenbush and Fisher 2001); ages will be referred to hereafter.

Counts of smallmouth bass made in channel units while snorkeling and electrofishing were adjusted to estimate abundance. To adjust snorkel counts, we constructed a model using counts and habitat variables to predict abundance. The model was built with study-independent data collected from channel units that were snorkeled first and then electrofished with three passes. Electrofishing abundance estimates were made using a three-pass capture probability model in which the number of individuals collected was divided by electrofishing capture probability (Dauwalter and Fisher 2007a). Electrofishing abundance estimates were then modeled as a function of snorkel counts and count interactions with fish size $(0,<100 ; 1, \geq 100 \mathrm{~mm})$ and habitat variables (water clarity, channel-unit depth, percent bedrock, and wood density). A no-intercept model was fit with all variables using SAS version 9.1 software (SAS Institute Inc., Cary, North Carolina). Variables with a significant effect $(P \leq 0.15)$ on abundance estimates were retained and the model was refit. The final model used to adjust snorkel counts was

$$
\begin{aligned}
& \hat{N}=2.6176(\text { snorkel count }) \\
& +0.1478(\text { snorkel count } \times \text { percent bedrock }) \\
& \quad-1.6354(\text { snorkel count } \times \text { size class })
\end{aligned}
$$

The model fit well (adjusted $R^{2}=0.79, N=59$ ). When channel units were electrofished because they were too turbid to snorkel, counts of smallmouth bass were adjusted using a one-pass electrofishing capture probability model (Dauwalter and Fisher 2007a).

\section{Data analysis}

We used a principle components analysis (PCA) to determine relationships among variables at the watershed and reach scales and to eliminate redundant covariables. The PCA was conducted on the correlation matrix, and eigenvalues greater than those predicted under the broken-stick model were considered meaningful (Jackson 1993; McGarigal et al. 2000). The predicted eigenvalue (b) for the $k$ th component under the broken-stick model was calculated as $b_{k}=\sum_{i=k}^{p} 1 / i$, where $p$ was the number of variables. Pearson correlations were used to examine relationships among channel-unit variables; the limited number of variables precluded use of PCA at the channel-unit spatial scale. Analyses were run using SAS version 9.1 software (SAS Institute Inc., Cary, North Carolina).

We used regression tree analysis (RTA) to determine the influence of ecoregions, watershed and reach morphology, and stream habitat at the reach and channel-unit spatial scales on the density of smallmouth bass in channel units. RTA is a flexible and robust nonparametric method used to assess complex relationships between explanatory variables and a response variable that may be nonlinear with highorder interactions. It explains variation in the response variable by splitting the data set into homogenous groups using 
Fig. 1. Sites selected (175) and sampled (128) for an inventory of watershed and reach morphology, stream habitat, and smallmouth bass (Micropterus dolomieu) in eastern Oklahoma streams.

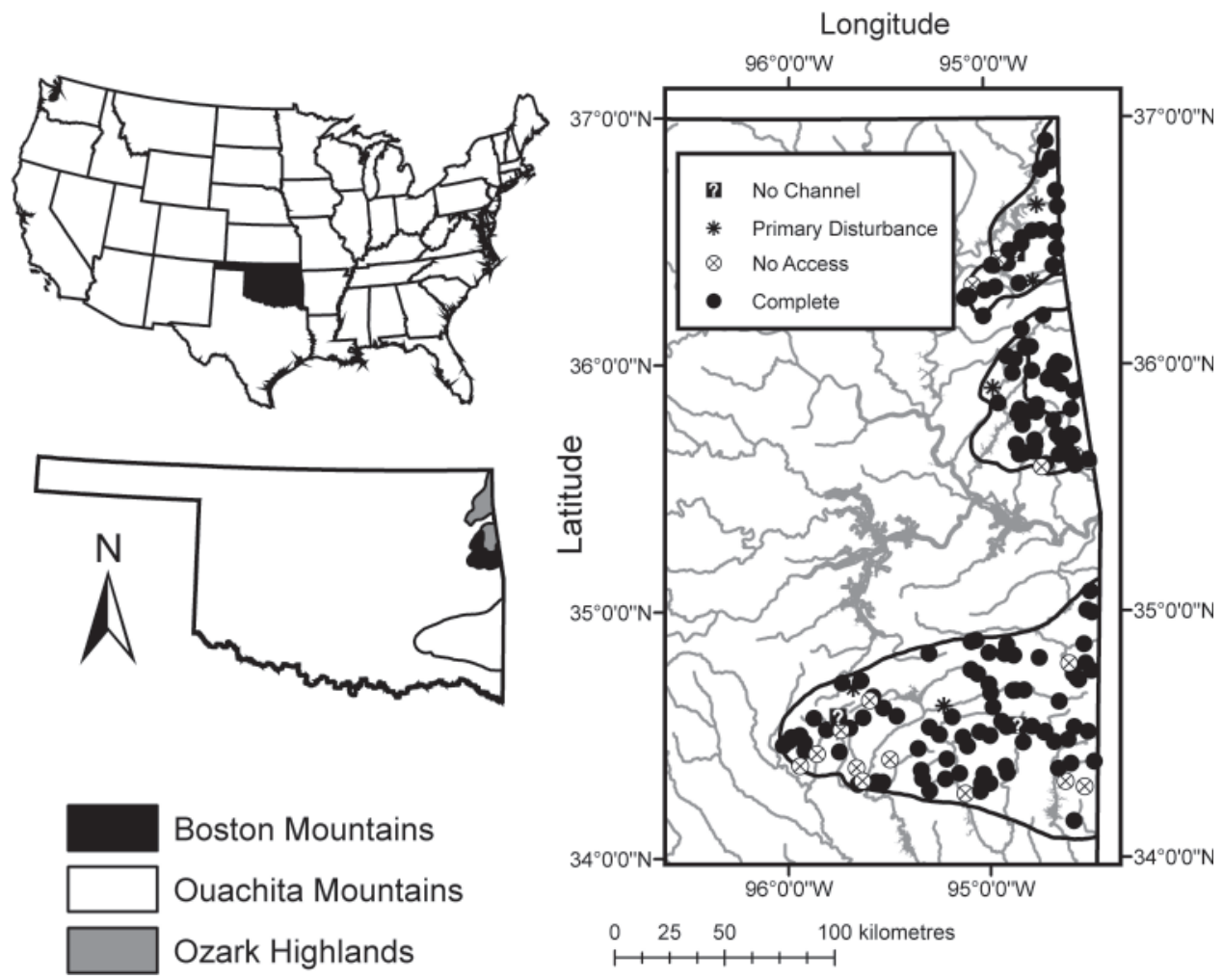

specific values of the categorical or continuous explanatory variables. Groups include observations that have common values of explanatory and response variables. Regression trees are displayed graphically for ease of interpretation (Breiman et al. 1984; De'ath and Fabricius 2000). RTA has been used in other ecological studies of complex relationships between explanatory and response variables when common linear modeling approaches have failed (Rejwan et al. 1999; De'ath and Fabricius 2000).

We conducted RTA for data collected at the ecoregion, watershed and reach, and channel-unit scales in one analysis for each age group. Although sample reaches were our defined sample units for the study, we defined each channel unit as an observation during RTA. Because RTA is a nonparametric analysis, the use of channel units as an observation when they are nested within reaches is not problematic. Explanatory variables included in RTA were dependent on results of PCA and correlation analyses to limit variable redundancy. Smallmouth bass densities (number $\cdot \mathrm{ha}^{-1}$ ) were natural $\log$ transformed $(\log (X+0.01))$ to reduce the effects of zero densities on variances. Each RTA was performed with CART version 6.2 software (Steinberg and Colla 1995). We used sums of squares about the group means as the measure to maximize homogeneity within groups; sums of absolute deviations about the median are more robust but can be ineffective when many zeros are present (De'ath and Fabricius 2000). The final tree selected was the one with the smallest relative error (similar to the coefficient of nondetermination, $1-r^{2}$ ) based on 10-fold cross-validation (Breiman et al. 1984; De'ath and Fabricius 2000).

\section{Results}

\section{Stream survey}

We surveyed channel morphology, stream habitat, and smallmouth bass abundance at 128 of 175 selected stream sites. Seventeen stream sites were either inaccessible or access was denied by landowners. Direct channel alteration by humans (e.g., gravel mining) was observed at five stream sites, and these sites were not sampled. Twenty-two streams were dry. Two sites were not snorkeled, and habitat measurements were incomplete at another. Complete information on watershed and reach morphology, stream habitat, and smallmouth bass abundance was collected at 128 stream sites (Fig. 1); electrofishing was conducted at 17 sites in the Ouachita Mountains. Among all sites, 1800 channel units were sampled.

\section{Watershed and channel morphology and habitat}

Watershed and channel morphology and stream habitat were more similar in the Boston Mountains and Ozark Highlands than in the Ouachita Mountains (Table 1). Ouachita Mountains streams had smaller watershed sizes on average, likely because most small streams in the other ecoregions were dry and excluded from analyses. Ouachita Mountains streams generally had higher reach slopes, larger particle sizes, and more vegetation, silt-clay substrate, and pool area. They were also typically deeper and had less wood and lower width-depth ratios than streams in the other regions. Stream reaches in the Boston Mountains were typically shallower and had more bedrock. Ozark Highland streams were 
Table 1. Morphology of watersheds and stream reaches in the Boston Mountains $(n=29)$, Ouachita Mountains $(n=$ 78), and Ozark Highlands $(n=21)$ ecoregions in eastern Oklahoma.

\begin{tabular}{|c|c|c|c|c|}
\hline Variable & & Boston Mountains & Ouachita Mountains & Ozark Highlands \\
\hline \multirow[t]{3}{*}{ Watershed area $\left(\mathrm{km}^{2}\right)$} & Mean & 116.1 & 61.5 & 182.0 \\
\hline & Minimum & 1.3 & 1.2 & 4.8 \\
\hline & Maximum & 587.5 & 393.5 & 951.3 \\
\hline \multirow[t]{3}{*}{$D_{50}(\mathrm{~mm})$} & Mean & 35.4 & 79.6 & 27.6 \\
\hline & Minimum & 2.7 & 1.5 & 16.8 \\
\hline & Maximum & 83.5 & 309.0 & 51.5 \\
\hline \multirow[t]{3}{*}{ Elongation ratio } & Mean & 0.57 & 0.53 & 0.49 \\
\hline & Minimum & 0.43 & 0.22 & 0.32 \\
\hline & Maximum & 0.82 & 0.84 & 0.67 \\
\hline \multirow[t]{3}{*}{ Large woody debris $\left(\right.$ no. $\left.\cdot \mathrm{m}^{-2}\right)$} & Mean & 0.0034 & 0.0030 & 0.0030 \\
\hline & Minimum & 0.0000 & 0.0000 & 0.0000 \\
\hline & Maximum & 0.0405 & 0.0235 & 0.0113 \\
\hline \multirow[t]{3}{*}{ Mean thalweg depth (m) } & Mean & 0.30 & 0.37 & 0.43 \\
\hline & Minimum & 0.11 & 0.10 & 0.22 \\
\hline & Maximum & 0.72 & 1.89 & 0.83 \\
\hline \multirow[t]{3}{*}{ Percent bedrock } & Mean & 16.9 & 10.5 & 8.4 \\
\hline & Minimum & 0.0 & 0.0 & 0.0 \\
\hline & Maximum & 88.5 & 67.7 & 68.8 \\
\hline \multirow[t]{3}{*}{ Percent pool } & Mean & 63.8 & 86.2 & 62.9 \\
\hline & Minimum & 11.6 & 23.2 & 34.6 \\
\hline & Maximum & 98.9 & 100.0 & 100.0 \\
\hline \multirow[t]{3}{*}{ Percent silt-clay } & Mean & 4.2 & 7.5 & 5.2 \\
\hline & Minimum & 0.0 & 0.0 & 0.0 \\
\hline & Maximum & 30.2 & 45.0 & 24.9 \\
\hline \multirow[t]{3}{*}{ Percent vegetation } & Mean & 2.0 & 8.2 & 3.8 \\
\hline & Minimum & 0.0 & 0.0 & 0.0 \\
\hline & Maximum & 17.6 & 61.1 & 17.4 \\
\hline \multirow[t]{3}{*}{ Rootwads $\left(\right.$ no. $\cdot \mathrm{m}^{-2}$ ) } & Mean & 0.0033 & 0.0055 & 0.0072 \\
\hline & Minimum & 0.0000 & 0.0000 & 0.0000 \\
\hline & Maximum & 0.0595 & 0.0235 & 0.0593 \\
\hline \multirow[t]{3}{*}{ Sinuosity } & Mean & 1.14 & 1.16 & 1.18 \\
\hline & Minimum & 1.00 & 1.00 & 1.00 \\
\hline & Maximum & 1.51 & 3.04 & 1.80 \\
\hline \multirow[t]{3}{*}{ Slope } & Mean & 0.0069 & 0.0075 & 0.0045 \\
\hline & Minimum & 0.0008 & 0.0000 & 0.0005 \\
\hline & Maximum & 0.0274 & 0.0315 & 0.0194 \\
\hline \multirow[t]{3}{*}{ Width-depth ratio } & Mean & 23.1 & 16.9 & 27.5 \\
\hline & Minimum & 11.4 & 6.9 & 6.6 \\
\hline & Maximum & 44.0 & 36.7 & 54.7 \\
\hline \multirow[t]{3}{*}{ Wood $\left(\right.$ no. $\left.\cdot \mathrm{m}^{-2}\right)$} & Mean & 0.0067 & 0.0085 & 0.0102 \\
\hline & Minimum & 0.0000 & 0.0000 & 0.0000 \\
\hline & Maximum & 0.1000 & 0.1192 & 0.0593 \\
\hline
\end{tabular}

deeper with more wood, wider channels, smaller particle sizes, and less bedrock on average when compared with streams in the other two regions. Variability in watershed and reach morphology and stream habitat was often greater in the Ouachita Mountains, the largest ecoregion.

At the watershed and reach scales, PCA revealed two informative principle components according to the broken-stick criterion; however, the third principle component also appeared important (Table 2). Axis 1 reflected stream size. Larger streams were deeper and had lower channel slopes, confirming the expected relationships among these variables. Axis 2 represented channel morphology. Wide, shallow channels had less silts and clays, more riffle-pool structure, and more bedrock. Axis 3 represented a particle size axis, dominated by $D_{50}$, and followed by percent pool and sinuosity. PCA biplots showed that channel morphology (axis 2) did not differ in small streams (axis 1) among ecoregions, but it differed between the largest Ozark Highlands and Ouachita Mountains streams; channel morphology in the Ouachita Mountains was also more variable than in the Boston Mountains and Ozark Highlands (Fig. 2). The pattern of site scores on axis 3 suggested that streams in the Ouachita Mountains typically had larger substrates and more pool habitat and were less sinuous. 
Table 2. Statistics and eigenvalues for eigenvectors from a principal component analysis (PCA) of geomorphic and stream habitat variables from 128 stream reaches in the Boston Mountains, Ouachita Mountains, and Ozark Highlands ecoregions in eastern Oklahoma.

\begin{tabular}{lrrr}
\hline & PC 1 & PC 2 & PC 3 \\
\hline Summary statistics & & & \\
Observed eigenvalue & 2.448 & 1.785 & 1.345 \\
Broken-stick eigenvalue & 1.000 & 1.500 & \multicolumn{1}{c}{1.833} \\
Percent of variance explained & 20.4 & 14.9 & 11.2 \\
Variables & & & \\
Watershed area $\left(\mathrm{km}^{2}\right)$ & 0.402 & 0.332 & 0.055 \\
$D_{50}(\mathrm{~mm})$ & -0.027 & 0.166 & 0.621 \\
Elongation ratio & -0.255 & 0.018 & 0.273 \\
Mean thalweg depth (m) & 0.458 & 0.097 & 0.324 \\
Percent bedrock & -0.086 & 0.353 & -0.141 \\
Percent pool & 0.253 & -0.349 & 0.427 \\
Percent silt-clay & 0.219 & -0.447 & -0.144 \\
Percent vegetation & 0.138 & -0.113 & 0.009 \\
Sinuosity & 0.154 & -0.277 & -0.377 \\
Slope & -0.544 & 0.020 & 0.115 \\
Width-depth ratio & 0.107 & 0.528 & -0.208 \\
Wood (no. $\mathrm{m}^{-2}$ ) & -0.306 & -0.195 & 0.100 \\
\hline
\end{tabular}

\section{Channel-unit habitat}

We sampled 11 channel-unit types in all. Riffles, runs, and midchannel pools were the most abundant types in each ecoregion. Habitat characteristics were highly variable among channel-unit types and ecoregions (Table 3). No variables among the 1800 channel units were highly correlated (Table 4). Velocity and mean thalweg depth had the highest Pearson correlation at $r=-0.398$.

\section{Smallmouth bass abundance}

Smallmouth bass densities varied widely but were typically higher in the Boston Mountains and Ozark Highlands. No smallmouth bass were collected in turbid stream reaches that were electrofished. Density estimates of age-0 smallmouth bass in channel units ranged from $0 \cdot \mathrm{ha}^{-1}$ in all ecoregions to $9406 \cdot \mathrm{ha}^{-1}$ in the Boston Mountains, $2331 \cdot \mathrm{ha}^{-1}$ in the Ouachita Mountains, and 4873. $\mathrm{ha}^{-1}$ in the Ozark Highlands. Densities of age-1 and older smallmouth bass ranged from $0 \cdot \mathrm{ha}^{-1}$ in all ecoregions to $8914 \cdot \mathrm{ha}^{-1}$ in the Boston Mountains, $775 \cdot \mathrm{ha}^{-1}$ in the Ouachita Mountains, and 4642. $\mathrm{ha}^{-1}$ in the Ozark Highlands. Densities were consistently high in runs and pools, although some riffles, abandoned channels, and backwaters also had high densities (Table 5).

Stream size, channel-unit depth, and reach morphology variables explained variation in densities of age-0 smallmouth bass. Seven watershed-reach and seven channel-unit scale variables were included in RTAs. Although reach slope was correlated with watershed area, we retained both because of the variability observed in the Ouachita Mountains ecoregion. Rootwad and large woody debris densities were combined (added) to form a wood density variable. Elongation ratio was not included because of the lack of direct biological influence on fish abundance. The regression tree with
Fig. 2. Principal component analysis (PCA) biplots of watershed and reach morphology and habitat of 128 stream reaches in the Boston Mountains (solid circles), Ouachita Mountains (shaded triangles), and Ozark Highlands (open squares) ecoregions, eastern Oklahoma. Axis 1 represented stream size, where slope $(-0.544)$, mean thalweg depth $(0.458)$, and watershed area (0.402) had the highest axis loadings ( $a$ and $b)$. Axis 2 represented channel stability; width-depth ratio (0.528), percent silt-clay $(-0.447)$, and percent bedrock $(0.353)$ had high axis loadings $(a) . D_{50}(0.621)$, percent pool $(0.427)$, and sinuosity $(-0.377)$ had high axis loadings for axis $3(b)$.

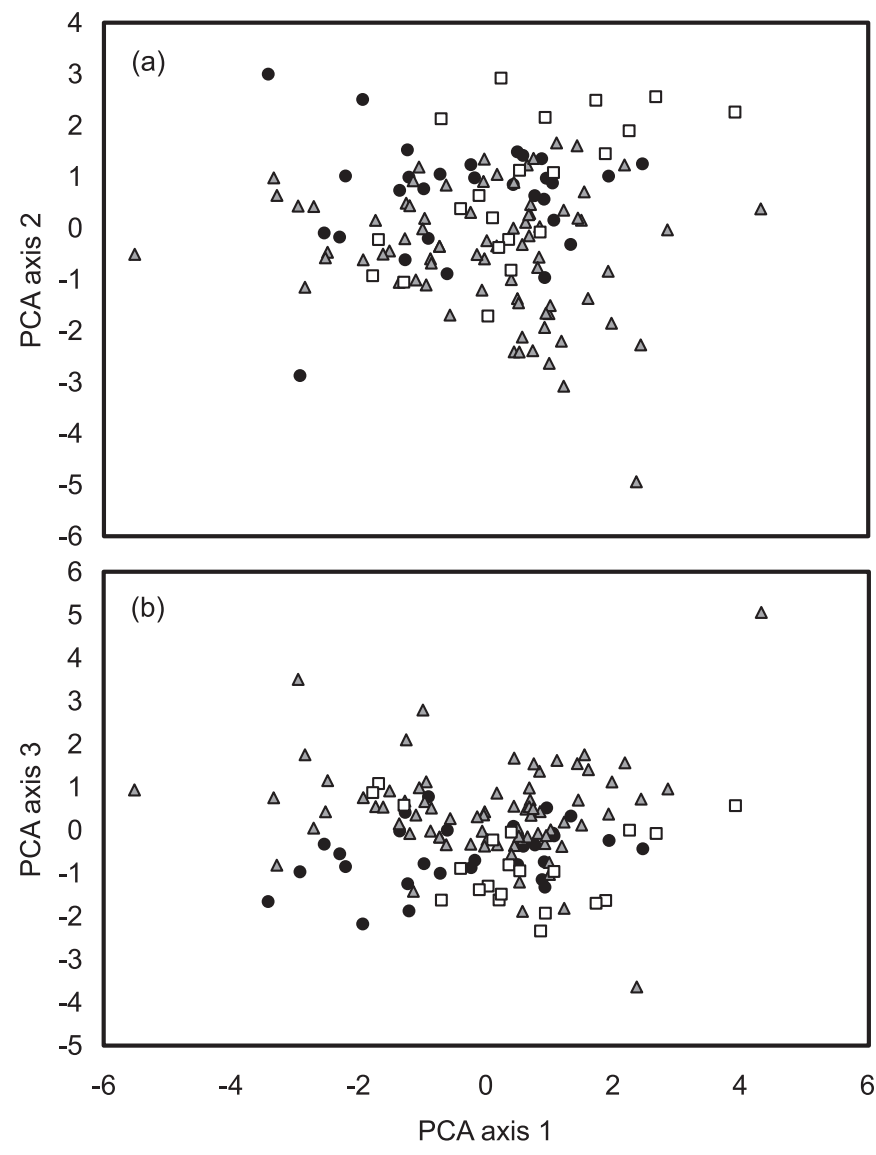

the minimum cross-validated relative error, 0.843 , had five nodes, three that were terminal (Fig. 3). We conducted an exploratory analysis by extending the tree to nine and 15 nodes that had relative errors of 0.866 and 0.867 , respectively. Thus, although the total amount of explained variation in densities of age-0 smallmouth bass was low (13\%-15\%), some variables explained variation at a higher probability than could be expected by chance. Age-0 densities were higher in deeper channel units in larger streams. In deeper channel units of larger streams, densities were higher in reaches with channel slopes greater than $0.07 \%$ and widthdepth ratios less than 25 . When width-depth ratios were higher than 25, age-0 densities were higher in deeper channel units. When densities were high in shallow channel units, they were high in higher gradient reaches (Fig. 3).

Several watershed-reach and channel-unit variables explained most of the variation in densities of age- 1 and older 
Table 3. Habitat characteristics of common channel-units types in streams of the Boston Mountains, Ouachita Mountains, and Ozark Highlands ecoregions in eastern Oklahoma.

\begin{tabular}{|c|c|c|c|c|c|c|}
\hline Variable & & Riffle & Run & Midchannel pool & Lateral pool & Backwater \\
\hline \multicolumn{7}{|l|}{ Boston Mountains } \\
\hline Number $(n)$ & & 191 & 183 & 160 & 16 & 31 \\
\hline \multirow[t]{3}{*}{ Mean depth (m) } & Mean & 0.156 & 0.307 & 0.329 & 0.526 & 0.304 \\
\hline & Minimum & 0.03 & 0.07 & 0.05 & 0.07 & 0.07 \\
\hline & Maximum & 0.55 & 1.08 & 1.67 & 1.04 & 0.72 \\
\hline Percent bedrock & Mean & 19.4 & 23.9 & 20.3 & 4.4 & 4.2 \\
\hline \multirow[t]{3}{*}{ Percent boulder } & Mean & 7.7 & 5.0 & 5.9 & 5.4 & 2.4 \\
\hline & Minimum & 0 & 0 & 0 & 0 & 0 \\
\hline & Maximum & 75 & 80 & 60 & 15 & 15 \\
\hline \multirow[t]{3}{*}{ Percent silt-clay } & Mean & 0.4 & 1.3 & 2.9 & 12.3 & 10.1 \\
\hline & Minimum & 0 & 0 & 0 & 0 & 0 \\
\hline & Maximum & 10 & 20 & 80 & 85 & 50 \\
\hline \multirow[t]{3}{*}{ Velocity (coded) } & Mean & 3 & 2 & 1 & 1 & 1 \\
\hline & Minimum & 3 & 2 & 1 & 1 & 1 \\
\hline & Maximum & 3 & 2 & 1 & 1 & 1 \\
\hline \multirow[t]{3}{*}{ Wood $\left(\right.$ no. $\left.\cdot \mathrm{m}^{-2}\right)$} & Mean & 0.00875 & 0.01000 & 0.11812 & 0.08463 & 0.02307 \\
\hline & Minimum & 0.0000 & 0.0000 & 0.0000 & 0.0000 & 0.0000 \\
\hline & Maximum & 0.5882 & 0.6250 & 12.0482 & 0.9091 & 0.1427 \\
\hline \multicolumn{7}{|c|}{ Ouachita Mountains } \\
\hline Number $(n)$ & & 259 & 164 & 356 & 8 & 9 \\
\hline \multirow[t]{3}{*}{ Mean depth (m) } & Mean & 0.123 & 0.265 & 0.375 & 0.610 & 0.403 \\
\hline & Minimum & 0.01 & 0.03 & 0.03 & 0.18 & 0.06 \\
\hline & Maximum & 0.83 & 0.76 & 1.63 & 1.89 & 1.15 \\
\hline \multirow{2}{*}{ Percent silt-clay } & Minimum & 0 & 0 & 0 & 1 & 0 \\
\hline & Maximum & 45 & 90 & 70 & 25 & 40 \\
\hline \multirow[t]{3}{*}{ Percent vegetation } & Mean & 13.2 & 5.4 & 8.7 & 3.8 & 6.9 \\
\hline & Minimum & 0 & 0 & 0 & 0 & 0 \\
\hline & Maximum & 99 & 70 & 95 & 10 & 30 \\
\hline \multirow[t]{3}{*}{ Velocity (coded) } & Mean & 3 & 2 & 1 & 1 & 1 \\
\hline & Minimum & 3 & 2 & 1 & 1 & 1 \\
\hline & Maximum & 3 & 2 & 1 & 1 & 1 \\
\hline \multirow[t]{3}{*}{ Wood $\left(\right.$ no. $\left.\cdot \mathrm{m}^{-2}\right)$} & Mean & 0.01460 & 0.05080 & 0.01415 & 0.00415 & 0.00422 \\
\hline & Minimum & 0.0000 & 0.0000 & 0.0000 & 0.0000 & 0.0000 \\
\hline & Maximum & 0.3682 & 3.8760 & 0.6667 & 0.0139 & 0.0180 \\
\hline \multicolumn{7}{|l|}{ Ozark Highlands } \\
\hline Number $(n)$ & & 105 & 113 & 92 & 10 & 46 \\
\hline \multirow[t]{3}{*}{ Mean depth (m) } & Mean & 0.254 & 0.475 & 0.518 & 0.636 & 0.382 \\
\hline & Minimum & 0.04 & 0.12 & 0.13 & 0.15 & 0.10 \\
\hline & Maximum & 0.71 & 1.42 & 1.97 & 1.17 & 1.09 \\
\hline Percent bedrock & Mean & 8.6 & 9.6 & 6.8 & 6.0 & 1.8 \\
\hline & Minimum & 0 & 0 & 0 & 0 & 0 \\
\hline & Maximum & 100 & 90 & 95 & 10 & 35 \\
\hline
\end{tabular}


Table 3 (concluded).

\begin{tabular}{|c|c|c|c|c|c|c|}
\hline Variable & & Riffle & Run & Midchannel pool & Lateral pool & Backwater \\
\hline \multirow[t]{2}{*}{ Percent boulder } & Mean & 0.8 & 1.5 & 1.3 & 3.7 & 1.0 \\
\hline & Minimum & 0 & 0 & 0 & 0 & 0 \\
\hline \multirow[t]{3}{*}{ Percent silt-clay } & Mean & 2.5 & 3.5 & 6.0 & 2.6 & 30.3 \\
\hline & Minimum & 0 & 0 & 0 & 0 & 0 \\
\hline & Maximum & 85 & 80 & 70 & 10 & 100 \\
\hline Percent vegetation & Maximum & 90 & 80 & 80 & 15 & 95 \\
\hline \multirow[t]{3}{*}{ Velocity (coded) } & Mean & 3 & 2 & 1 & 1 & 1 \\
\hline & Minimum & 3 & 2 & 1 & 1 & 1 \\
\hline & Maximum & 3 & 2 & 1 & 1 & 1 \\
\hline Wood $\left(\right.$ no. $\left.\cdot \mathrm{m}^{-2}\right)$ & Mean & 0.00764 & 0.01829 & 0.01490 & 0.00288 & 0.02148 \\
\hline
\end{tabular}

Note: All variables were included in regression tree analyses.

Table 4. Pearson correlations $(r)$ between habitat variables of 1800 channel units in 128 stream reaches in the Boston Mountains, Ouachita Mountains, and Ozark Highlands ecoregions in eastern Oklahoma.

\begin{tabular}{llllrrr}
\hline Variable & Percent vegetation & Percent bedrock & Percent boulder & Percent silt-clay & Velocity & Wood \\
\hline Mean depth & -0.053 & -0.033 & -0.005 & 0.146 & -0.398 & -0.046 \\
Percent vegetation & & -0.096 & 0.045 & 0.060 & 0.047 & -0.025 \\
Percent bedrock & & -0.144 & -0.135 & -0.001 & -0.018 \\
Percent boulder & & & -0.155 & 0.068 & 0.003 \\
Percent silt-clay & & & & -0.223 & 0.008 \\
Velocity & & & & -0.039 \\
\hline
\end{tabular}

smallmouth bass. Variables included in the RTA were the same as those for age- 0 smallmouth bass. The regression tree with the minimum cross-validated relative error, 0.650 , had 19 splitting nodes and 20 terminal nodes (Fig. 4). Shallow channel units, regardless of stream size, had the lowest densities, followed by deeper channel units in small streams. However, high densities were observed in some shallow channel units of large streams when bedrock was present. Densities in deeper channel units of small streams were higher, but only in deep channel units of wide, shallowchannel reaches or when substrates were pebble or larger. The highest densities of age- 1 and older smallmouth bass were found in deep channel units of large streams that had well-developed riffle-pool morphology ( $<90 \%$ pool). Densities were higher in channel units intermediate in depth (0.33-0.42m) when substrates were large and channel slope was greater than $0.2 \%$. However, the highest densities occurred in the deepest channel units where bedrock was present. When bedrock was not present, densities were higher when vegetation coverage was less than $5 \%$ and substrate composition consisted of few fines (Fig. 4).

\section{Discussion}

Densities of smallmouth bass in eastern Oklahoma streams were related to watershed morphology, reach morphology, and channel-unit characteristics in complex ways. There was no overriding influence of one spatial scale on smallmouth bass density. The influence of each scale was dependent on specific conditions at other scales, likely reflecting the linkage among scales (Frissell et al. 1986). These complex relationships were elucidated by use of regression tree analysis and would have been difficult to establish using linear modeling techniques; others have successfully used regression tree analysis to elucidate complex relationships between smallmouth bass nest densities and lake habitats (Rejwan et al. 1999). The models can also be used to predict smallmouth bass densities at a site from measured variables and guide management expectations that change channel morphology or channel-unit characteristics.

Interestingly, ecoregion did not have a direct influence on smallmouth bass density. We found that densities in streams of northeastern Oklahoma ecoregions were higher than those in the southeast, as shown in other studies (Stark and Zale 1991; Balkenbush and Fisher 2001). However, regional differences in smallmouth bass densities were more related to variation in reach morphology in larger streams with high densities than they were to ecoregions. Variation in reach morphology of large streams reflected differences in lithology, sediment regimes, land use, and hydrology among ecoregions (Woods et al. 2005; Splinter 2006), but also incorporated spatial variability among watersheds and local processes within ecoregions. Changes in land use, hydrology, and temperature that are reflective of large-scale processes have previously been shown to affect smallmouth bass populations (Peterson and Kwak 1999). Thus, although smallmouth bass abundance does differ among ecoregions, it is more closely linked with reach morphology that reflects 
Table 5. Smallmouth bass densities (no. $\cdot \mathrm{ha}^{-1}$ ) per age group per channel-unit type in streams of the Boston Mountains, Ouachita Mountains, and Ozark Highlands ecoregions in eastern Oklahoma.

\begin{tabular}{|c|c|c|c|c|c|}
\hline \multirow[b]{2}{*}{ Channel-unit type } & \multirow[b]{2}{*}{$n$} & \multicolumn{2}{|l|}{ Age-0 } & \multicolumn{2}{|c|}{ Age- 1 and older } \\
\hline & & Mean & Range & Mean & Range \\
\hline \multicolumn{6}{|l|}{ Boston Mountains } \\
\hline Abandoned channel & 4 & 278.5 & $0-1114.1$ & 0.0 & $0-0$ \\
\hline Backwater & 31 & 78.7 & $0-1228.7$ & 17.2 & $0-434$ \\
\hline Debris pool & 2 & 0.0 & $0-0$ & 0.0 & $0-0$ \\
\hline Eddy pool & 2 & 0.0 & $0-0$ & 239.6 & $0-479$ \\
\hline Fall & 3 & 0.0 & $0-0$ & 0.0 & $0-0$ \\
\hline Lateral pool & 16 & 62.0 & $0-341$ & 98.3 & $0-492$ \\
\hline Midchannel pool & 160 & 58.6 & 0-2071 & 143.2 & $0-5851$ \\
\hline Plunge pool & 3 & 0.0 & $0-0$ & 0.0 & $0-0$ \\
\hline Riffle & 191 & 5.4 & $0-50$ & 0.3 & $0-42$ \\
\hline Run & 183 & 122.3 & 0-9406 & 254.8 & $0-8914$ \\
\hline Sheet & 5 & 0.0 & $0-0$ & 0.0 & $0-0$ \\
\hline \multicolumn{6}{|l|}{ Ouachita Mountains } \\
\hline Abandoned channel & 1 & 0.0 & $0-0$ & 0.0 & $0-0$ \\
\hline Backwater & 9 & 0.0 & $0-0$ & 0.0 & $0-0$ \\
\hline Eddy pool & 3 & 0.0 & $0-0$ & 0.0 & $0-0$ \\
\hline Fall & 4 & 0.0 & $0-0$ & 0.0 & $0-0$ \\
\hline Lateral pool & 8 & 0.0 & $0-0$ & 0.0 & $0-0$ \\
\hline Midchannel pool & 356 & 14.8 & 0-2096 & 8.0 & $0-775$ \\
\hline Riffle & 259 & 3.0 & $0-335$ & 1.1 & $0-277$ \\
\hline Run & 164 & 36.1 & $0-2331$ & 12.3 & $0-629$ \\
\hline \multicolumn{6}{|l|}{ Ozark Highlands } \\
\hline Abandoned channel & 1 & 0.0 & $0-0$ & 0.0 & $0-0$ \\
\hline Backwater & 46 & 68.7 & $0-1216$ & 19.9 & $0-370$ \\
\hline Debris pool & 1 & 0.0 & $0-0$ & 0.0 & $0-0$ \\
\hline Eddy pool & 11 & 241.8 & $0-1377$ & 654.5 & $0-4642$ \\
\hline Fall & 2 & 0.0 & $0-0$ & 208.6 & $0-417$ \\
\hline Lateral pool & 10 & 78.2 & $0-463$ & 156.2 & $0-458$ \\
\hline Midchannel pool & 98 & 16.1 & $0-161$ & 146.4 & $0-2749$ \\
\hline Plunge pool & 2 & 0.0 & $0-0$ & 0.0 & $0-0$ \\
\hline Riffle & 110 & 49.9 & $0-4873$ & 42.8 & $0-4179$ \\
\hline Run & 113 & 40.5 & $0-785$ & 160.7 & $0-3793$ \\
\hline Sheet & 2 & 0.0 & $0-0$ & 0.0 & $0-0$ \\
\hline
\end{tabular}

ecoregion characteristics rather than being directly related to ecoregions themselves.

Larger streams had deeper channel units and higher densities of smallmouth bass. This likely reflected the distribution of spawning adults and spawning habitat. Small streams have stochastic stream flows and habitat that limit smallmouth bass reproduction (Orth and Newcomb 2002), and adults typically spawn in large, deep pools (Reynolds and O'Bara 1991) that are more common in larger streams. Densities were also higher in streams with wide, shallow channels. Large streams in the Ozark Highlands typically exhibited these characteristics and generally have an abundance of spawning gravels. They also have very high densities of nesting smallmouth bass (Dauwalter and Fisher $2007 b$ ). Floods in northeastern Oklahoma streams are also of less magnitude but longer duration than floods in southeastern streams (Dauwalter 2006), and these streamflow characteristics have been related to increased smallmouth bass abundance (Peterson and Kwak 1999).
Smallmouth bass densities did not decrease in the largest streams we sampled. This reflected our sampling design. Had we sampled larger streams (e.g., > fourth order), we likely would have observed decreased densities or absence of smallmouth bass (Stark and Zale 1991; Rabeni and Jacobson 1993); in Baron Fork Creek, smallmouth bass densities were higher in a fourth-order reach when compared with a fifth-order reach (Dauwalter 2006). Rabeni and Jacobson (1993) suggested that smallmouth bass densities in Ozark streams decrease with increased valley width owing to finer bedload materials and less bluff pools, which are important smallmouth bass habitats. Increased stream temperatures downstream may also limit smallmouth populations (Zweifel et al. 1999). Thus, intermediate-sized streams and rivers in eastern Oklahoma likely provide the streamflow and habitat conditions most suitable for smallmouth bass populations.

Channel morphology was primarily important in explaining densities of smallmouth bass in large streams and deep channel units. Width-depth ratio typically reflects channel 
Fig. 3. Regression tree analysis of effects of ecoregion, watershed and reach morphology and habitat, and channel-unit habitat on age-0 smallmouth bass (Micropterus dolomieu) densities (no. ha $^{-1}$ ) in 1800 channel units from 128 stream reaches in three eastern Oklahoma ecoregions. Mean densities per node (avg) are given, as are standard deviation (SD) and sample size $(N)$. Terminal nodes are oval. Tenfold cross-validated relative error was 0.843 in the original analysis and 0.866 and 0.867 in exploratory analyses.

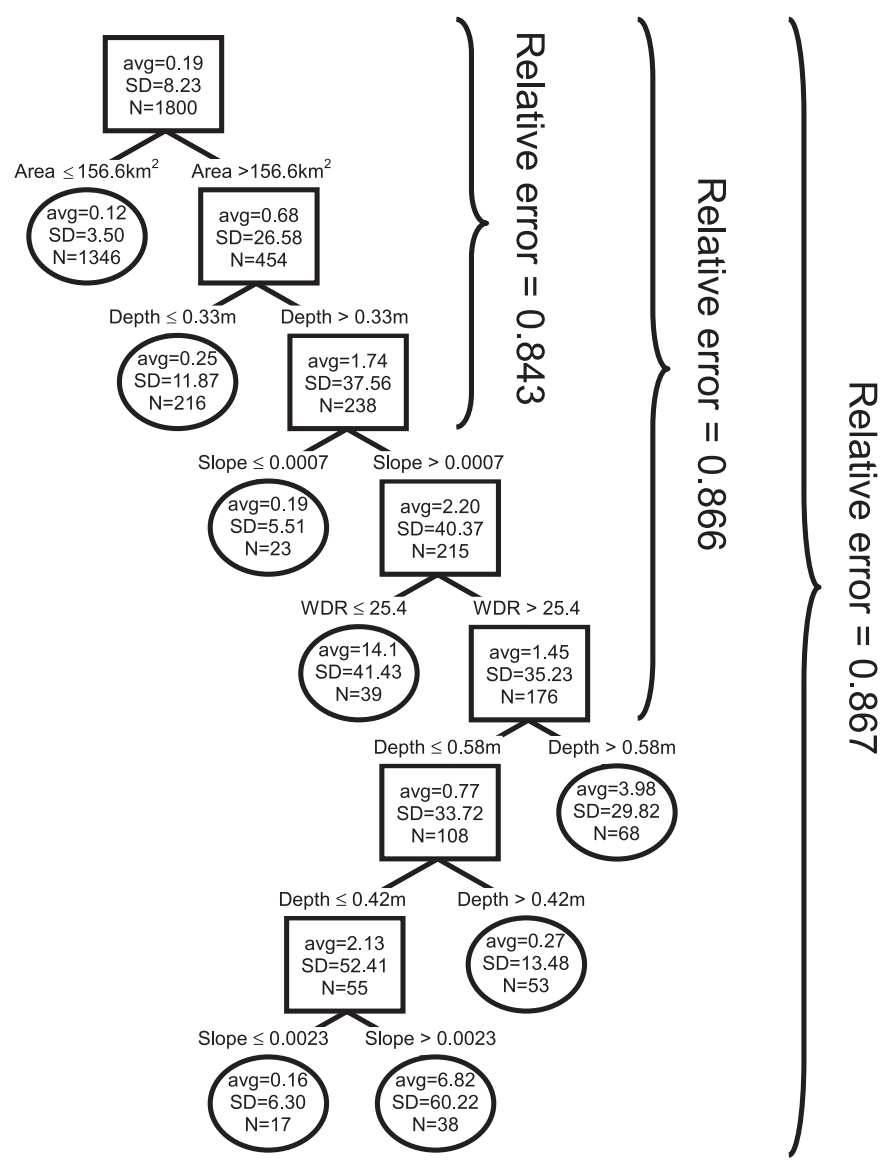

stability and percent silt-clay in the channel perimeter and banks (both negatively related) and is positively related to discharge and sediment loads; sinuosity also reflects siltclay content of banks and typically varies inversely with width-depth ratio (Knighton 1998). In the Ozark Highlands, accelerated erosion due to past clearing of forests and current overgrazing has likely increased runoff and bedload dynamics, resulting in wider, gravel-dominated channels (Rabeni and Jacobson 1993; Splinter 2006). Increased channel width also results in less canopy cover per stream width. This may increase production of stream invertebrates beneficial to fishes, such as juvenile smallmouth bass (Livingstone and Rabeni 1991), as long as the increased sediment load is primarily gravel and not fines (Waters 1995). We also found that reaches with more riffle-pool structure (less percent pool overall) in larger streams had higher smallmouth bass densities. In Missouri streams, smallmouth bass densities were higher in streams with less pool habitat (Sowa and Rabeni 1995). Crayfish production has been reported to be higher in riffles than pools in larger streams (Roell and Orth
1992). Thus, as riffle-pool ratios decrease there may be less crayfish production per reach, leading to reduced prey availability to smallmouth bass.

Except for water depth, channel-unit habitat was not related to age- 0 densities of smallmouth bass, and habitat was mostly related to densities of age- 1 and older bass in deeper channel units of larger streams. Densities of age- 0 and age- 1 and older smallmouth bass were higher in deeper channel units and were typically very low or zero in shallow ones regardless of stream size. Predators like smallmouth bass typically occupy deeper habitats of streams (Schlosser 1987), and they do not use depths less than about $0.25 \mathrm{~m}$ regardless of size (Orth and Newcomb 2002; Fore et al. 2007). Avoidance of shallow water may be a behavioral adaptation to circumvent predation by terrestrial vertebrates. Although deep channel units were present in both small and large streams, deeper channel units were more prevalent in larger streams. Consequently, densities were higher overall in the larger streams we sampled. Age-0 smallmouth bass are typically generalized in habitat use (Sabo and Orth 1994). Swimming ability of age- 0 individuals may also prohibit them from moving into desired channel units, especially between pools separated by riffles. Consequently, densities of age- 0 smallmouth bass in channel units may reflect the quality of spawning habitat (Cleary 1956), number of successful nests and nest production (Reynolds and O'Bara 1991; Lukas and Orth 1995), and (or) survival dynamics of fry and juveniles through their first summer (Knotek and Orth 1998).

Densities of age- 1 and older smallmouth bass were only related to channel-unit habitat (other than depth) in a few instances. Densities were higher in shallow channel units of larger streams when bedrock was present. In deep channel units of large streams, densities were also higher when bedrock was present. Local bed scour occurs along bedrock outcroppings and can create deep areas in even shallow channel units. We also observed no density relationship with boulders, as was reported in Jacks Fork River, Missouri (McClendon and Rabeni 1987). Boulders have been associated with bluff pools, which are important habitats for smallmouth bass (Rabeni and Jacobson 1993). We also found that densities were lower when more vegetation was present. Use of vegetation can be detrimental to age-0 smallmouth bass when compared with other habitats (Olson et al. 2003); however, vegetation had no effect on densities in other studies (McClendon and Rabeni 1987). Channel units with a fraction of silt-clay substrate also had low smallmouth bass densities. Fine sediments represent unsuitable habitat for the benthic macroinvertebrates and crayfishes consumed by smallmouth bass in these streams (Waters 1995; Pflieger 1996; Fenner et al. 2004), and smallmouth bass have been shown to be absent more often when reaches had more fine substrates (Lyons 1991).

The effects of spatial scale need to be considered in the management and conservation of smallmouth bass. Ecoregions represent the largest scale we studied. The differences in abundance of sport fishes like smallmouth bass among ecoregions led to identification of ecoregional-based fishery management regions in eastern Oklahoma (northeast, east-central, and southeast; Fisher et al. 2004). Of the components used to delineate ecoregions, land use is the only one that can be actively managed. Management of land use 
Fig. 4. Regression tree analysis of effects of ecoregion, watershed and reach morphology and habitat, and channel-unit habitat on age-1 and older smallmouth bass (Micropterus dolomieu) densities (no. $\mathrm{ha}^{-1}$ ) in 1800 channel units from 128 stream reaches in three eastern Oklahoma ecoregions. Mean densities per node (avg) are given, as are standard deviation (SD) and sample size $(N)$. Terminal nodes are oval. Tenfold cross-validated relative error was 0.650 . Broad descriptions of channel units related to primary splits are given.

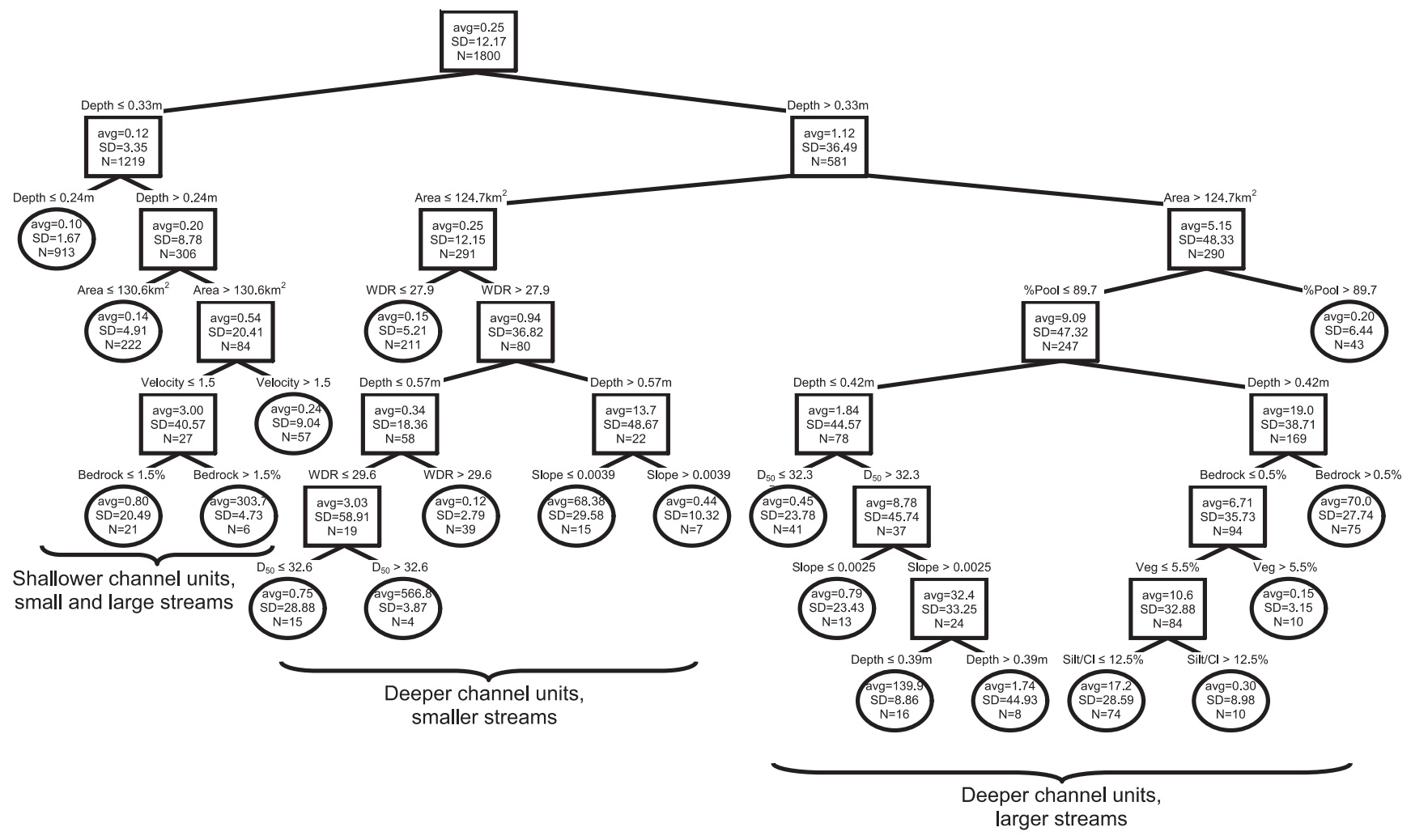

on a large scale (ecoregions or watersheds) is likely to be slow and problematic. However, long-term changes in land use can be beneficial to smallmouth bass populations. Conversion of land from forest or prairie to agriculture can increase flood magnitude and reduce flood pulse duration. Floods in north temperate regions occur in spring when smallmouth bass spawn, and increased flood magnitude during spawning can adversely affect population size (Peterson and Kwak 1999). The contributing watershed and subsequent size of a stream also cannot be actively managed. Management at the ecoregion and watershed scales is more likely to involve strategies tailored for specific regional or stream conditions. For example, fishing regulations may be tailored for streams in each region, and the expected catch rates of anglers and responses of fish populations to habitat management should be adjusted to regions and stream size.

Stream habitat management at the reach and channel-unit spatial scales is more logistically and fiscally feasible and has a long history (White 1996). Reach morphology is an indicator of stream condition, and stream reaches are often classified to guide instream habitat management (Rosgen 1994; Kondolf et al. 2003). Changing reach morphology is often a goal of habitat management, especially alteration of riffle-pool ratios and channel width-depth ratios (Roni et al. 2005). We found that smallmouth bass were more abundant in streams with riffle-pool morphology, and they have been shown to respond negatively to anthropogenic activities that increase channel widths, alter riffle-pool morphology, and pool depth (Brown et al. 1998). Instream structures are often used to narrow and deepen stream channels and create deep pools used by sport fishes (Binns 1994). Restoration of riparian vegetation can also promote bank stability and change channel morphology. It can also moderate water temperatures in summer (Poole and Berman 2001) and benefit growth, and possibly population size, of smallmouth bass (Whitledge et al. 2006). Addition of wood, boulders, and other habitat within channel units is another habitat management practice. Smallmouth bass are typically associated with specific microhabitats, including cover. However, our data suggest that substrate and vegetation characteristics become important to smallmouth bass only after channel-unit size, stream size, and channel morphology result in locally favorable habitat conditions; similar interactions between spatial scales were suggested for Missouri streams (McClendon and Rabeni 1987; Rabeni and Sowa 1996). Thus, microhabitats likely influence the spatial distribution of smallmouth bass in a channel unit but do not strongly influence production or population dynamics like larger scale factors do (Rabeni and Sowa 1996), and although addition of instream cover can sometimes be useful to effect change in fish populations and communities (House 1996), it should not replace maintenance or re-establishment of the large-scale processes of water, sediment, and wood delivery that create reach characteristics favorable to smallmouth bass populations (Poole et al. 1997).

The need to understand how physical characteristics of streams influence stream fishes at multiple spatial scales is not a new concept (Frissell et al. 1986; Wiens 2002) but is 
essential for effective stream management. We observed strong stream-size effects, but geomorphic influences on smallmouth bass were complex and different between small and large streams. Rabeni and Sowa (1996) stressed the importance of realizing the nestedness of spatial scales and understanding how factors acting on different spatial scales are important to the conservation of stream fishes. Geomorphic processes are naturally hierarchical, and understanding spatial variability associated with those processes is important to understanding how they structure fish habitat in streams (Montgomery 1999). Most often, large-scale processes influence stream morphology and function at smaller spatial scales, but local impacts do not always influence large-scale processes. There are exceptions, as upstream and downstream channel adjustments may occur from a localized disturbance. Consequently, many stream restoration and habitat enhancement projects have a geomorphic basis that includes different spatial scales (Rosgen 1996; Federal Interagency Stream Restoration Working Group 1998; Montgomery and Bolton 2003). Understanding how smallmouth bass populations relate to large-scale factors, channel morphology, and channel-unit habitat, as shown here, is essential in realizing how certain conservation and management practices might influence this popular sport fish (Fisher et al. 2002) and indicator species (Hlass et al. 1998) of these upland regions in the central United States.

\section{Acknowledgments}

We thank V. Horncastle, S. Davis, A. Krystyniak, B. Marston, R. Ary, K. Winters, M. Murray, and J. Morel for field assistance. J. Bidwell, A. Echelle, and two anonymous reviewers commented on manuscript drafts. Project funding was provided by a Federal Aid in Sport Fish Restoration Act grant under Project F-55-R of the Oklahoma Department of Wildlife Conservation and the Oklahoma Cooperative Fish and Wildlife Research Unit. The Oklahoma Cooperative Fish and Wildlife Research Unit is jointly sponsored by the US Geological Survey, Oklahoma State University, the Oklahoma Department of Wildlife Conservation, the Wildlife Management Institute, and the US Fish and Wildlife Service. D. Dauwalter was supported by a fellowship for Water, Energy, and the Environment from the Environmental Institute, Oklahoma State University.

\section{References}

Bain, M.B. 1999. Substrate. In Aquatic habitat assessment: common methods. Edited by M.B. Bain and N.J. Stevenson. American Fisheries Society, Bethesda, Maryland. pp. 95-103.

Balkenbush, P.E., and Fisher, W.L. 2001. Population characteristics and management of black bass in eastern Oklahoma streams. Proceedings of the Southeastern Association of Fish and Wildlife Agencies, 53: 130-143.

Baxter, C.V., and Hauer, F.R. 2000. Geomorphology, hyporheic exchange, and selection of spawning habitat by bull trout (Salvelinus confluentus). Can. J. Fish. Aquat. Sci. 57: 1470-1481.

Benda, L., Poff, N.L., Miller, D., Dunne, T., Reeves, G., Pess, G., and Pollock, M. 2004. The network dynamics hypothesis: how channel networks structure riverine habitat. Bioscience, 54: 413-427.
Beschta, R.L., and Platts, W.S. 1986. Morphological features of small streams: significance and function. Water Resour. Bull. 22: 370-379.

Binns, N.A. 1994. Long-term responses of trout and macrohabitats to habitat management in a Wyoming headwater stream. N. Am. J. Fish. Manag. 14: 87-98.

Breiman, L., Friedman, J., Olshen, R., and Stone, C. 1984. Classification and regression trees. Wadsworth International Group, Belmont, California.

Brown, A.V., Lyttle, M.M., and Brown, K.B. 1998. Impacts of gravel mining on gravel bed streams. Trans. Am. Fish. Soc. 127: 979-994.

Champoux, O., Biron, P.M., and Roy, A.G. 2003. The long-term effectiveness of fish habitat restoration practices: Lawrence Creek, Wisconsin. Ann. Assoc. Am. Geographers, 93: 42-54.

Cleary, R.E. 1956. Observations on factors affecting smallmouth bass production in Iowa. J. Wildl. Manag. 20: 353-359.

Dauwalter, D.C. 2006. Relationships among geomorphology, habitat, and fishes in eastern Oklahoma streams: implications for stream restoration. Ph.D. thesis, Oklahoma State University, Stillwater, Oklahoma.

Dauwalter, D.C., and Fisher, W.L. 2007a. Electrofishing capture probability of smallmouth bass in streams. N. Am. J. Fish. Manag. 27: 162-171.

Dauwalter, D.C., and Fisher, W.L. 2007b. Spawning chronology, nest site selection, and nest success of smallmouth bass during benign streamflow conditions. Am. Midl. Nat. 158: 60-78.

Dauwalter, D.C., Fisher, W.L., and Belt, K.C. 2006. Mapping stream habitats with a global positioning system: accuracy, precision, and comparison with traditional methods. Environ. Manag. 37: 271280.

De'ath, G., and Fabricius, K.E. 2000. Classification and regression trees: a powerful yet simple technique for ecological data analysis. Ecology, 81: 3178-3192.

Dolloff, A., Kershner, J., and Thurow, R. 1996. Underwater observation. In Fisheries techniques. Edited by B.R. Murphy and D.W. Willis. American Fisheries Society, Bethesda, Maryland. pp. 533-554.

Fenner, D.B., Walsh, M.G., and Winkelman, D.L. 2004. Diet overlap of introduced rainbow trout and three native fishes in an Ozark stream. Am. Fish. Soc. Symp. 44: 475-482.

Fisher, W.L., Schreiner, D.F., Martin, C.D., Negash, Y.A., and Kessler, E. 2002. Recreational fishing and socioeconomic characteristics of eastern Oklahoma stream anglers. Proc. Okla. Acad. Sci. 82: 79-87.

Fisher, W.L., Tejan, E.C., and Balkenbush, P.E. 2004 Regionalization of stream fisheries management using Geographic Information Systems. In Proceedings of the 2nd International Symposium on GIS/Spatial Analyses in Fishery and Aquatic Sciences. Edited by T. Nishida, P.J. Kailola, and C.E. Hollingworth. Fishery-Aquatic GIS Research Group, Kawagoe, Saitama, Japan. pp. 465-476.

Federal Interagency Stream Restoration Working Group. 1998. Stream corridor restoration: principles, processes, and practices. The Federal Interagency Stream Restoration Working Group (FISRWG) (15 federal agencies of the US gov't). GPO Item No. 0120; SuDocs No. 57.6/2:EN3/PT.653. ISBN-0-934213-59-3.

Fore, J.D., Dauwalter, D.C., and Fisher, W.L. 2007. Microhabitat use by smallmouth bass in an Ozark stream. J. Freshw. Ecol. 22(2): 189-199.

Frissell, C.A., Liss, W.J., Warren, C.E., and Hurley, M.D. 1986. A hierarchical framework for stream habitat classification: viewing streams in a watershed context. Environ. Manag. 10: 199-214.

Frothingham, K.M., Rhoads, B.L., and Herricks, E.E. 2002. A multiscale conceptual framework for integrated ecogeomorpho- 
logical research to support stream naturalization in the agricultural Midwest. Environ. Manag. 29: 16-33.

Gido, K.B., Falke, J.A., Oakes, R.M., and Hase, K.J. 2006. Fishhabitat relations across spatial scales in prairie streams. In Landscape influences on stream habitats and biological assemblages. Edited by R.M. Hughes, L. Wang, and P.W. Seelbach. Am. Fish. Soc. Symp. 48: 265-285.

Hawkins, C.P., Kershner, J.L., Bisson, P.A., Bryant, M.D., Decker, L.M., Gregory, S.V., McCullough, D.A., Overton, C.K., Reeves, G.H., Steedman, R.J., and Young, M.K. 1993. A hierarchical approach to classifying stream habitat features. Fisheries, 18(6): $3-12$.

Hlass, L.J., Fisher, W.L., and Turton, D.J. 1998. Use of the index of biotic integrity to assess water quality in forested streams in the Ouachita Mountains ecoregion, Arkansas. J. Freshw. Ecol. 13: $181-192$.

House, R. 1996. An evaluation of stream restoration structures in a coastal Oregon stream 1981-1993. N. Am. J. Fish. Manag. 16: 272-281.

Huryn, A.D., and Wallace, J.B. 1987. Local geomorphology as a determinant of macrofaunal production in a mountain stream. Ecology, 68: 1932-1942.

Jackson, D.A. 1993. Stopping rules in PCA: a comparison of heuristical and statistical approaches. Ecology, 74: 2205-2214.

Knighton, D. 1998. Fluvial forms and processes: a new perspective. Oxford University Press, Inc., New York.

Knotek, W.L., and Orth, D.J. 1998. Survival for specific life intervals of smallmouth bass, Micropterus dolomieu, during parental care. Environ. Biol. Fishes, 51: 285-296.

Kondolf, G.M., Montgomery, D.R., Piéjay, H., and Schmitt, L. 2003. Geomorphic classification of rivers and streams. In Tools in geomorphology. Edited by G.M. Kondolf and H. Piéjay. John Wiley \& Sons Ltd., West Sussex, England. pp. 171-204.

Livingstone, A.C., and Rabeni, C.F. 1991. Food-habitat relations of underyearling smallmouth bass in an Ozark stream. In The First International Smallmouth Bass Symposium. Edited by D.C. Jackson. Mississippi Agricultural and Forestry Experiment Station, Mississippi State University, Mississippi State, Miss. pp. 76-83.

Lukas, J.A., and Orth, D.J. 1995. Factors affecting nesting success of smallmouth bass in a regulated Virginia stream. Trans. Am. Fish. Soc. 124: 726-735.

Lyons, J. 1991. Predicting smallmouth bass presence/absence and abundance in Wisconsin streams using physical habitat characteristics. In The First International Smallmouth Bass Symposium. Edited by D.C. Jackson. Mississippi Agricultural and Forestry Experiment Station, Mississippi State University, Mississippi State, Miss. pp. 96-103.

McClendon, D.D., and Rabeni, C.F. 1987. Physical and biological variables useful for predicting population characteristics of smallmouth bass and rock bass in an Ozark stream. N. Am. J. Fish. Manag. 7: 46-56.

McGarigal, K., Cushman, S., and Stafford, S. 2000. Multivariate statistics for wildlife and ecology research. Springer-Verlag, New York.

Miranda, L.E., and Dolan, C.R. 2003. Test of a power transfer model for standardizing electrofishing. Trans. Am. Fish. Soc. 132: 1179-1185.

Montgomery, D.R. 1999. Process domains and the river continuum. J. Am. Water Resour. Assoc. 36: 397-410.

Montgomery, D.R., and Bolton, S.M. 2003. Hydrogeomorphic variability and river restoration. In Strategies for restoring river ecosystems: sources of variability and uncertainty in natural and managed systems. Edited by R.C. Wissmar and P.A. Bisson. American Fisheries Society, Bethesda, Maryland. pp. 39-80.
Morisawa, M. 1968. Streams: their dynamics and morphology. McGraw-Hill Book Company, New York.

Newson, M.D., and Newson, C.L. 2000. Geomorphology, ecology and river channel habitat: mesoscale approaches to basin-scale challenges. Prog. Phys. Geog. 24: 195-217.

Olson, M.H., Young, B.P., and Blinkoff, K.D. 2003. Mechanisms underlying habitat use of juvenile largemouth bass and smallmouth bass. Trans. Am. Fish. Soc. 132: 398-405.

Omernik, J.M. 1987. Ecoregions of the conterminous United States. Ann. Assoc. Am. Geographers, 77: 118-125.

Orth, D.J., and Newcomb, T.J. 2002. Certainties and uncertainties in defining essential habitats for riverine smallmouth bass. In Black bass: ecology, conservation, and management. Edited by D.P. Philipp and M.S. Ridgway. Am. Fish. Soc. Symp. 31: 251-264.

Peterson, J.T., and Kwak, T.J. 1999. Modeling the effects of land use and climate change on riverine smallmouth bass. Ecol. Appl. 9: $1391-1404$.

Pflieger, W.L. 1996. The crayfishes of Missouri. Missouri Department of Conservation, Jefferson City, Missouri.

Poole, G.C., and Berman, C.H. 2001. An ecological perspective on instream temperature: natural heat dynamics and mechanisms of human-caused thermal degradation. Environ. Manag. 27: 787-802.

Poole, G.C., Frissell, C.A., and Ralph, S.C. 1997. In-stream habitat unit classification: inadequacies for monitoring and some consequences for management. J. Am. Water Resour. Assoc. 33: 879896.

Rabeni, C.F., and Jacobson, R.B. 1993. Geomorphic and hydraulic influences on the abundance and distribution of stream centrarchids in Ozark USA streams. Pol. Arch. Hydrobiol. 40: 87-99.

Rabeni, C.F., and Sowa, S.P. 1996. Integrating biological realism into habitat restoration and conservation strategies for small streams. Can. J. Fish. Aquat. Sci. 53(Suppl. 1): 252-259.

Rejwan, C., Collings, N.C., Brunner, L.J., Shuter, B.J., and Ridgway, M.S. 1999. Tree regression analysis on the nesting habitat of smallmouth bass. Ecology, 80: 341-348.

Reynolds, C.R., and O'Bara, C.J. 1991. Reproductive ecology and spawning habitat of smallmouth bass in two small streams of the Tennessee River system. In The First International Smallmouth Bass Symposium. Edited by D.C. Jackson. Mississippi Agricultural and Forestry Experiment Station, Mississippi State, Miss. pp. 61-65.

Rhoads, B.L., Schwartz, J.S., and Porter, S. 2003. Stream geomorphology, bank vegetation, and three-dimensional habitat hydraulics for fish in midwestern agricultural streams. Water Resour. Res. 39: 1218.

Roell, M.J., and Orth, D.J. 1992. Production of three crayfish populations in the New River of West Virginia, USA. Hydrobiologia, 228: $185-194$.

Roni, P., Fayram, A.H., and Miller, M.A. 2005. Monitoring and evaluating instream habitat enhancement. In Monitoring stream and watershed restoration. Edited by P. Roni. American Fisheries Society, Bethesda, Maryland. pp. 209-236.

Rosgen, D.L. 1994. A classification of natural rivers. Catena, 22: 169-199.

Rosgen, D.L. 1996. Applied river morphology. Wildland Hydrology, Pagosa Springs, Colorado.

Rutherford, D.A., Echelle, A.A., and Maughan, O.E. 1992. Drainage-wide effects of timber harvesting on the structure of stream fish assemblages in southeastern Oklahoma. Trans. Am. Fish. Soc. 121: 716-728.

Sabo, M.J., and Orth, D.J. 1994. Temporal variation in microhabitat use by age- 0 smallmouth bass in the North Anna River, Virginia. Trans. Am. Fish. Soc. 123: 733-746. 
Schlosser, I.J. 1987. A conceptual framework for fish communities in small warmwater streams. In Community and evolutionary ecology of North American stream fishes. Edited by W.J. Matthews and D.C. Heins. University of Oklahoma Press, Norman, Okla. pp. 17-24.

Sowa, S.P., and Rabeni, C.F. 1995. Regional evaluation of the relation of habitat to distribution and abundance of smallmouth bass and largemouth bass in Missouri streams. Trans. Am. Fish. Soc. 124: $240-251$.

Splinter, D.K. 2006. Spatial patterns in the fluvial system: comparisons among three eastern Oklahoma ecoregions. Ph.D. thesis, Oklahoma State University, Stillwater, Oklahoma.

Stark, W.J., and Zale, A.V. 1991. Status of smallmouth bass populations in eastern Oklahoma. Oklahoma Department of Wildlife Conservation, Oklahoma City, Federal Aide Project No. F-41-R.

Steinberg, D., and Colla, P. 1995. CART: tree-structured nonparametric data analysis. Salford Systems, San Diego, California.

Strahler, A.N. 1957. Quantitative analysis of watershed geomorphology. Trans. Am. Geophys. Union, 38: 913-920.

US Geological Survey. 1999. National elevation dataset. 1st ed. US Geological Survey, Sioux Falls, South Dakota.

Vannote, R.L., Minshall, G.W., Cummins, K.W., and Cushing, C.E. 1980. The river continuum concept. Can. J. Fish. Aquat. Sci. 37: 130-137.

Walters, D.M., Leigh, D.S., Freeman, M.C., Freeman, B.J., and Pringle, C.M. 2003. Geomorphology and fish assemblages in a Piedmont river basin, U.S.A. Freshw. Biol. 48: 1950-1970.
Waters, T.F. 1995. Sediment in streams: sources, biological effects, and control. American Fisheries Society Monograph 7, Bethesda, Maryland.

White, R.J. 1996. Growth and development of North American stream habitat management for fish. Can. J. Fish. Aquat. Sci. 53(Suppl. 1): 342-363.

Whitledge, G.W., Rabeni, C.F., Annis, G., and Sowa, S.P. 2006. Riparian shading and groundwater enhance growth potential for smallmouth bass in Ozark streams. Ecol. Appl. 16: 1461-1473.

Wiens, J.A. 2002. Riverine landscapes: taking landscape ecology into the water. Freshw. Biol. 47: 501-515.

Woods, A.J., Omernik, J.M., Butler, D.R., Ford, J.G., Henley, J.E., Hoagland, B.W., Arndt, D.S., and Moran, B.C. 2005. Ecoregions of Oklahoma (color poster with map, descriptive text, summary tables, and photographs). US Geological Survey, Reston, Virginia.

Yang, C.T. 1971. Formation of riffles and pools. Water Resour. Res. 7: 1567-1574.

Zar, J.H. 1999. Biostatistical analysis. Prentice Hall, Upper Saddle River, New Jersey.

Zweifel, R.D., Hayward, R.S., and Rabeni, C.F. 1999. Bioenergetics insight into black bass distribution shifts in Ozark border region streams. N. Am. J. Fish. Manag. 19: 192-197. 